\title{
PECULIARITIES OF THE PSYCHOLOGICAL TIME IN THE CONTEXT OF GLOBALIZATION. COMPARATIVE STUDY OF RUSSIA AND JAPAN
}

\author{
Wada Toshihiro ${ }^{1}$, Ekaterina Zabelina ${ }^{2}$, Yulia Chestyunina ${ }^{2}, \&$ Irina Trushina ${ }^{2}$ \\ ${ }^{1}$ Department of Law, Ehime University (Japan) \\ ${ }^{2}$ Department of Psychology and Pedagogics, Chelyabinsk State University (Russia)
}

\begin{abstract}
Because of the increasing flow of information in modern society, perceptions of personal time are changing. Psychological time becomes the universal aspect of life that allows marking changes in personality in the era of globalization. The purpose of this study is to identify similarities and differences of subjective (psychological) time in two countries Russia and Japan, which are quite different on the political, economic, and cultural levels. The theoretical basis of the study is the model of time perception according to T. Nestik (2016). According to this model, cognitive, affective, motivational and behavioral components of psychological time are studied among the students of regional universities in Russia and Japan $(\mathrm{N}=593)$. Respondents completed paper forms of Inventory of Time Value as an Economic Resource (Usunier), Zimbardo Time Perspective Inventory, Attitudes towards Time (Nuttin), and Inventory of Polychronic Values (Bluedorn). The results of the comparative analysis revealed that there are differences in all components of psychological time. Russian students are more positive about their past than the Japanese because the past is more joyful, bright, and pleasant for them. It is connected with good memories. Japanese students are more focused on having a good time in the present, not always thinking about what will be in the future. They are more inclined to perceive the events that happen to them in the present as fatal, regardless of their will. At the same time, there are no differences in the vision for the future. Regardless of their cultural affiliation, students worry about their future, make plans and also try to create an action plan for the future, so it would be more predictable. Japanese students are generally more restrained in positive emotions when assessing their time, while Russian students are more optimistic about it. Russian students tend towards polychronicity (the habit of doing a few things at a time) more than the Japanese. Russian students determine the value of time as an economic resource more accurately, they can transform time into money more easily, and they know the cost of their time as well. The results of the study indicate that culture (language) continues to play an important differentiating role in the world, despite the processes of globalization. However, the impact of globalization is noticeable in such aspects as the desire to avoid uncertainty and willingness to live the moment. The results of the study can be used in advising students on their future professional choices as well as on how to live a psychologically healthy life in modern society.
\end{abstract}

Keywords: Psychological time, Russia, Japan, future, past positive.

\section{Introduction}

Because of inflation of traditional values, openness of social systems, unification of forms relations and behavior under the influence of globalization, modern societies face a certain mobility of perception and attitude toward time. Time and its subjective perception becomes a marker that highlights the trends of the global society: acceleration of the pace of life, erasure of the boundaries of the personal and professional sphere, and permanent deficit of time as a life resource (Zabelina, Smirnov, Chestyunina, 2016). In this regard, the study of psychological time in the conditions of globalization becomes more and more significant in terms of human wellbeing in the modern society.

In particular, the research on the subjective (psychological) time of young generations of various countries is relevant, because young people are involved in globalization faster and more actively. At the same time, the more different cultural patterns of social communities, the more significant the evidence of globalization trends will be. That is why for this study we chose two countries with different, largely contrasting cultures - Japan and Russia. The aim of this study is to identify similarities and differences in subjective (psychological) time of young people in these countries. 
Psychological time has a wide definition. It is "a perception and experience of the objective time of one's life, representations of time, caused both by personal experience of individual and group life, and by learned social, historical and cultural experience, awareness of time, personal attitude to time, psychological organization and regulation of life time" (Kovalyov, 1988, p.217)

The theoretical basis of the study is the model of relation to time proposed by T. Nestik (2015). This model includes four components of the relation to time. Value and motivational component includes subjective importance of time as an irreplaceable resource. Cognitive component is illustrated by time perspective, temporal aspects of identity, etc. Affective component reflects emotional relation to time, and behavioral one describes preferred methods of time organization (Nestik, 2015, p.100).

\section{Method and sample}

The theoretical model was verified in the study of students from regional Russian and Japanese universities. The sample included 593 people: 293 students aged from 18 up to 23 years from Russia, 75 males, 218 females, and 279 students from Japan, aged from 18 up to 24 years, 121 males and 158 females. All the students study in full-time faculties of humanities.

Inventory of Time Value as an Economic Resource by Usunier (Nestik, 2015) was used to explore the content of the value and motivational component of psychological time. To study the cognitive component of psychological time, Zimbardo Time Perspective Inventory (Mitina, Sirtzova, 2008) was used. In order to identify the content of the affective component of psychological time, Attitudes towards Time (Nuttin, 2004) was used. This technique is based on a semantic differential, allowing to study emotional attitude to the past, present and future. Inventory of Polychronic Values (Bluedorn) was used to study the content of the behavioral component of psychological time.

Before the main study, the techniques were translated from Russian into Japanese (direct and reverse translation), and all necessary validation procedures were performed. The forms of the questionnaires were presented to the respondents in hand copy. The data was processed using the SPSS 24.0. statistical package. For the comparative analysis Mann-Whitney U criterion was used.

\section{Results}

The results of the comparative analysis revealed differences in all components of psychological time. The results of the comparison of the cognitive component of psychological time are shown in Table 1.

Table 1. Results of comparative analysis of cognitive component of psychological time for Russians and Japanese.

\begin{tabular}{lcccc}
\hline & \multicolumn{2}{c}{ Mean rank } & U & $\mathrm{p}$ \\
\cline { 2 - 5 } & Russians & Japanese & & \\
\hline Past Negative & 262.53 & 344.08 & 34130 & 0.000 \\
\hline Present Hedonistic & 279.37 & 78781.50 & 38878.5 & 0.000 \\
\hline Future & 303.82 & 308.79 & 45775.5 & 0.729 \\
\hline Past Positive & 335.92 & 281.36 & 38234.5 & 0.000 \\
\hline Present Fatalistic & 277.16 & 331.57 & 38256 & 0.000 \\
\hline
\end{tabular}

The results show that Japanese students are more involved in the past, both positive and negative. They are more attentive to their experience, perceive joyful and sad events emotionally. At the same time, they are more focused on the present, on getting positive emotions from current events, to live fully the very moment. Furthermore, Japanese students more share the belief that what happens to them in the present is predetermined and does not depend on their efforts. At the same time, there were no differences in perception of the future: students, regardless of their cultural affiliation, worry about their future, make plans, seek to introduce certainty into them and make their future more understandable.

The analysis of the differences in the affective component of psychological time showed that Japanese students as a whole are more restrained in positive emotions when assessing their time. Russian students, on the contrary, are more optimistic in regards of the past, present and future (Table 2). 
Table 2. Results of comparative analysis of affective component of psychological time for Russians and Japanese.

\begin{tabular}{lcccc}
\hline & \multicolumn{2}{c}{ Mean rank } & U & $\mathrm{p}$ \\
\cline { 2 - 4 } & Russians & Japanese & & \\
\hline Attitude toward the past & 254,33 & 364,32 & 31408.5 & 0.000 \\
\hline Attitude toward the present & 279,02 & 342,33 & 38667 & 0.000 \\
\hline Attitude toward the future & 236,03 & 380,63 & 26026.5 & 0.000 \\
\hline
\end{tabular}

Japanese students assess their past, present and future more neutrally: time appears as emotionally balanced (causing neither pleasant feelings nor unpleasant ones), quite eventful, passing at an average pace (neither quickly nor slowly). It is moderately difficult, moderately successful, and moderately interesting. For the Russian sample the sense of personal control over the past, present and future is more typical. They perceive their time as more meaningful, active, belonging to themselves. For the Japanese sample, on the contrary, such control is less expressed. In their minds, time is less meaningful, more passive and refers, first of all, not to an individual, but to a certain social space.

The behavioral component of psychological time showed significant differences either. Russian students are more prone to polychromic way of life than the Japanese $(U=42940 ; p=0.013)$. If Russians are used to doing several things at the same time, pay attention to many things in one stage, the Japanese prefer to finish one task before taking on another.

The value and motivational component of psychological time also showed some differences $(\mathrm{U}=40766.5 ; \mathrm{p}=0.001)$. Russian students more accurately determine the value of time as an economic resource, easily translate time into money, can count the cost of their time. For Japanese students, time is not linked so tough with money. For example, they are calmer about standing in line (a waste of time) because it is a part of the public rules.

\section{Discussion}

The observed differences of psychological time in Japan and Russia, on the one hand, confirm the available data on the relationship between psychological time and culture (Graham, 1981: Levine, 1997: Trompenaars and Hampden-Turner, 1997; Vale et al., 2012), and on the other, clarify these data in the light of the processes of globalization.

Peculiarities of time perspective of the Japanese demonstrate the manifestations of perception of time due to culture. For example, for Japanese, time acts as a certain force which is not controlled by a person, and which subordinates a person to its will 時はすべてのものを貪り食う - 《time devours everything» (Pariyeva, 2017). Moreover, one can observe such feature of the Japanese attitude as a focus on the present moment which is much more important, than the past or the future 昨日は今日の昔 "yesterday is the past of today." (Smirnov, Smirnova, 2019).

E. Iskabulova (2018) stresses the importance of the past for the Japanese. The existence here and now owes above all to the past, the history and the experience of previous generations. In particular, in Japanese national self-awareness, linguistic analysis traces the treatment of the past as something sacral. In Japanese culture a person is a debtor of the past, and every day the contact with other people increases his debt in the present (Iskabulova, 2018).

The results of the study indicate that culture continues to play an important differentiating role in the world, despite the processes of globalization. However, the impact of globalization is noticeable in such aspects as the desire to avoid uncertainty, the desire to live the moment. The results of the study can be used in advising students on professional choices, psychologically healthy lives in modern society.

\section{Acknowledgments}

The reported study was funded by RFBR according to the research project № 18-013-00201 A. 


\section{References}

Graham, R.J. (1981). The Role of Perception of Time in Consumer Research. Journal of Consumer Research, 7, 335-342.

Hall E.T., Hall M.R. (1990). Understanding cultural differences. Yarmouth, ME: Intercultural Press.

Hall, E.T. (1976). Beyond Culture. Garden City, N.Y.: Anchor Books.

Iskabulova E.U. (2018). Otnoshenie ko vremeni v russkoj i yaponskoj lingvokul'turah [Attitude towards Time in Russian and Japanese Linguocultures]. Materialy VII Mezhdunarodnoj studencheskoj nauchnoj konferencii «Studencheskij nauchnyj forum. Retried August 28, 2019 from URL: https://scienceforum.ru/2015/article/2015011922

Kovalev V. I. (1988). Kategoriya vremeni v psihologii (lichnostnyj aspekt) [Category of Time in Psychology (Personality Aspect)]. Kategorii materialisticheskoj dialektiki v psihologii. Moscow. pp. 216-230.

Levine R.A (1997). Geography of time: The Temporal Misadventures of a Social Psychologist, or How Every Culture Keeps Time Just a Little Bit Differently. N.Y.: Basic Books.

Mitina, O.V., Syrtzova, A. (2008). Questionnaire on Time Perspective of F.Zimbardo (ZTPI) results of the psychometric analysis of the Russian version. Moscow University Psychology Bulletin, 4, 67-89.

Nestik T.A. (2015). Social'no-psihologicheskaya determinaciya gruppovogo otnosheniya $k$ vremeni [Social and psychological determination of group attitude to time] Doctoral thesis. Moscow

Nuttin, Zh. (2004). Motivaciya, dejstvie i perspektiva budushchego [Motivation, action and future perspective]. Moscow: Smysl.

Pariyeva N.E. (2017). Koncept «vremya» v yaponskoj lingvokul'ture [Concept "time" in Japanese linguoculture]. Doctoral thesis. Moscow

Sircova, A. (2008). Vozrastnaya dinamika vremennoi perspektivy lichnosti [Age dynamics of time perspective of the personality]. Moscow.

Smirnov M.G., Smirnova N. (2019). K voprosu o vospriyatii vremeni v sovremennom yaponskom sociume [To the question of the perception of time in modern Japanese society]. Vestnik Chelyabinskogo gosudarstvennogo universiteta, 8 (430), 75-82.

Trompenaars, F., Hampden-Turner, Ch., (1997). Riding the Waves of Culture. Nicholas Brealey Publ. Ltd.

Vale, G.L., Flynn, E.G. \& Kendal, R.L. (2012). Cumulative culture and future thinking: Is mental time travel a prerequisite to cumulative cultural evolution? Learning and Motivation. 43, 220-230.

Zabelina E.V., Smirnov M.G., Chestyunina Yu.V. (2016) Psihologicheskoe vremya lichnosti v usloviyah globalizacii: postanovka problemy [Psychological Time of a Personality in the Conditions of Globalization: State of the Problem]. Universum: psihologiya i obrazovanie, 9 (27). Retrieved September 28, 2016 from URL: http://7universum.com/ru/psy/archive/item/3607

Zimbardo, P.G. and Boyd, J.N. (1999) Putting time in perspective: A valid, reliable individual-differences metric. Journal of Personality and Social Psychology, 77 (6), 1271-1288. 